\title{
PROFIL KEMAMPUAN MATEMATIKA ANAK USIA DINI MELALUI LEARNING TO THINK DIFFERENT
}

\author{
Titin Faridatun Nisa' \\ Muhammad Busyro Karim \\ Program Studi Pendidikan Guru Pendidikan Anak Usia Dini Fakultas Ilmu Pendidikan \\ Universitas Trunojoyo Madura \\ email: titinfaridatunnisa@trunojoyo.ac.id \\ email: busyrokarim.dz@gmail.com
}

\begin{abstract}
Abstrak: Profil Kemampuan Matematika Anak Usia Dini Melalui Learning To Think Different. Penelitian ini bertujuan untuk mengetahui profil kemampuan matematika anak usia dini dalam learning to think different. Jenis penelitian ini adalah penelitian eksploratif dengan pendekatan kualitatif. Penelitian ini hasilnya akan dianalisis dengan menggunakan analisis kualitatif. Hasil penelitian menunjukkan bahwa gambaran profil kemampuan matematika anak usia dini pada kelompok anak dengan kemampuan di bawah rata-rata memiliki kesamaan dengan kelompok rata-rata dalam kemampuan berpikir logis dan simbolik dengan kategori berkembang sesuai harapan. Adapun untuk kemampuan berpikir kritisnya sama, yakni kategori mulai berkembang. Kelompok anak dengan kemampuan di bawah rata-rata memiliki kemampuan pemecahan masalah dengan kategori mulai berkembang, sedangkan kelompok anak dengan kemampuan rata — rata termasuk kategori berkembang sesuai dengan harapan.
\end{abstract}

Kata kunci: Kemampuan Matematika, Anak Usia Dini, Learning to Think Different

\begin{abstract}
Early Childhood Math Capability Profile Through Learning To Think Different. This study aims to determine the profile of early childhood math skills in learning to think different. The type of this research is explorative research with qualitative approach. This research results will be analyzed by using qualitative analysis. The results showed that the profile picture of early childhood math ability in the group of children with below average ability had similarities with the average group in logical and symbolic thinking ability with the categories evolving as expected. As for the ability to think critically the same, that category began to grow. A group of children with below average skills has problem-solving skills with the category beginning to develop, while the group of children with average ability including the category evolves according to expectations.
\end{abstract}

Keywords: Ability of Mathematics, Early Childhood, Learning to Think Different 
Pendidikan adalah merupakan aset penting bagi kemajuan sebuah bangsa. Oleh karena itu, setiap warga negara harus dan wajib mengikuti jenjang pendidikan, baik jenjang pendidikan anak usia dini, pendidikan dasar, pendidikan menengah maupun pendidikan tinggi. Kebanyakan orang tua mengabaikan pendidikan anak usia dini dalam memulai proses masuk ke lembaga pendidikan dengan alasan tidak ingin anaknya mengalami stres atau kehilangan masa bermain. Padahal untuk membiasakan diri dan mengembangkan pola pikir anak pendidikan sejak usia dini mutlak diperlukan.

Anak usia dini merupakan individu yang berbeda, unik, dan memiliki karakteristik tersendiri sesuai dengan tahapan usianya. Anak usia adala sosok individu yang sedang mengalami proses pertumbuhan dan perkembangan yang sangat pesat dan fundamental bagi kehidupan selanjutnya (Suhartiningsih dkk, 2013:75). Perkembangan anak usia dini sifatnya holistik, yaitu dapat berkembang optimal apabila sehat badannya, cukup gizinya, serta dididik secara baik dan benar. Untuk itu, saat ini anak perlu mendapat pendidikan yang sesuai dengan tahap perkembangannya (Idris, 2015:16-17).

Penyelenggaraan Pendidikan Anak Usia Dini (PAUD) merupakan pendidikan yang diselenggarakan dengan tujuan untuk memfasilitasi pertumbuhan dan perkembangan anak usia $0-6$ tahun secara menyeluruh atau menekankan pada pengembangan seluruh aspek kepribadian dan perkembangan anak agar anak memiliki kesiapan dalam memasuki pendidikan lebih lanjut (Sujiono, 2013: 6). Pendidikan bagi anak usia dini merupakan pemberian upaya untuk menstimulasi, membimbing, mengasuh, dan pemberian kegiatan pembelajaran yang akan menghasilkan kemampuan dan keterampilan anak. Konsekuensinya, lembaga PAUD perlu menyediakan berbagai kegiatan yang dapat mengembangkan berbagai aspek perkembangan seperti perkembangan fisik (koordinasi motorik halus dan kasar), kecerdasan, daya cipta, kecerdasan emosi, dan kecerdasan spiritual.

Dalam menjalankan beberapa aspek diatas, kemampuan guru akan menjadi faktor penting untuk diperhatikan. Hal ini karena guru memegang peran penting dalam membimbing murid-muridnya memperoleh ilmu pengetahuan yang dibutuhkan. Terlebih pada PAUD, peran guru menjadi sangat krusial karena otak anak pada usia itu sangat sensitif terhadap stimulasi. Berkaitan dengan hal tersebut sayangnya guru-guru PAUD di Indonesia belum semuanya memiliki pengetahuan dan kompetensi yang terstandar.

Perkembangan konsep matematika dan cara berpikir anak-anak dimulai jauh sebelum mereka memasuki jenjang sekolah. Anak-anak menghabiskan tahun-tahun pertama pertumbuhan mereka untuk mempelajari ruang dan angka dengan mengamati kehidupan dan lingkungan mereka. Namun, tidak seperti perkembangan bahasa, pertumbuhan matematis yang mulai berkembang ini sering tidak diperhatikan oleh orang tua dan pengasuh. Hal ini terjadi terutama karena adanya pemahaman yang telah meluas bahwa matematika adalah ilmu yang hanya berkaitan dengan menulis angka-angka dan menghitung.

Pemahaman tersebut sangat tidak benar. Menuliskan angka-angka adalah hal terakhir yang dilakukan. Yang pertama adalah munculnya gagasan-gagasan yang dibangun dari berbagai pengalaman dengan dunia beserta benda-benda yang ada di dalamnya. Ini adalah dasar bagi intuisi matematis yang kuat yang dapat dan harus ditingkatkan oleh orang tua dan orang lain yang membesarkan anakanak.

Pada umumnya, anak-anak senang belajar. Sebagaimana hakikat anak bahwa pada usia tersebut rasa keingintahuan anak sangat besar. Oleh karena itu, ada baiknya mereka dikenalkan pada matematika sejak dini. Akan tetapi, perlu berhati-hati jika mengenalkan 
matematika pada anak. Pengenalan matematika pada anak diharapkan untuk tidak memaksakan pada anak supaya mereka tidak membenci matematika. Hal yang perlu dilakukan guru dan orang tua adalah melakukan kegiatan matematika yang menyenangkan untuk melatih pola berpikir dan penalaran anak.

Matematika sebagai salah satu ilmu dasar, baik aspek terapan maupun aspek penalarannya memiliki peranan penting dalam upaya penguasaan ilmu dan teknologi. Anak dituntut untuk dapat menghadapi tantangan kehidupan yang global dan dapat memecahkan masalah yang ada pada kehidupannya. Tujuan pengenalan matematika pada anak usia dini dibagi menjadi dua, yakni tujuan umum dan tujuan khusus (Nisa' dkk, 2016:116). Adapun tujuan umumnya adalah agar anak mengetahui dasar-dasar pembelajaran berhitung/matematika, sehingga pada saatnya nanti anak akan lebih siap mengikuti pembelajaran matematika pada jenjang pendidikan selanjutnya yang lebih kompleks.

Tujuan khusus pengenalan matematika pada anak usia dini adalah sebagai berikut: 1) dapat berpikir logis dan sistematis sejak dini melalui pengamatan terhadap bendabenda kongkrit, gambar-gambar atau angkaangka yang terdapat di sekitar anak; 2) dapat menyesuaikan dan melibatkan diri dalam kehidupan masyarakat yang dalam kesehariannya memerlukan keterampilan berhitung; 3) memiliki ketelitian, konsentrasi, abstraksi, dan daya apresiasi yang tinggi; 4) memiliki pemahaman konsep ruang dan waktu serta dapat memperkirakan kemungkinan urutan sesuatu peristiwa terjadi di sekitarnya; 5) memiliki kreativitas dan imajinasi dalam menciptakan sesuatu secara spontan.

Sejalan dengan tujuan tersebut, penyajian konsep matematika yang akan disampaikan disesuaikan dengan perkiraan perkembangan intelektual anak, tidak langsung pada pengerjaan matematika. Penyajian konsep matematika dapat dilakukan dengan mengaitkan konsep yang akan disampaikan dengan realitas di sekitar anak. Pengaitan konsep matematika dengan realitas lingkungan sekitar anak dapat menstimulus kemampuan berpikir kritis anak. Kemampuan berpikir kritis masing-masing anak berbeda bergantung pada sejauh mana anak berinteraksi dengan lingkungannya.

$$
\text { Berpikir kritis merupakan }
$$

ketrampilan berpikir universal yang berguna untuk semua profesi dan jenis pekerjaan. Demikian juga berpikir kritis berguna dalam melakukan kegiatan membaca, menulis, berbicara, mendengarkan, berdiskusi, dan sebagainya, untuk mendapatkan hasil yang lebih baik. Analisis yang kritis dapat meningkatkan pemahaman tentang suatu masalah. Sehingga, anak yang memiliki kemampuan berpikir kritis yang baik akan mampu menyelesaikan masalahnya dengan baik.

Mengingat pentingnya pola pikir bagi anak, maka perlu diajarkan kemampuan berpikir kritis sejak dini. Pola pikir anak dapat diukur secara kognitif dan juga melalui kecerdasan logika atau penalaran. Pola pikir anak bisa dibentuk dengan melakukan latihan secara terus menerus dan jangka panjang. Dalam memupuk perkembangan pola pikir anak usia dini harus dilakukan dengan kesabaran dan tidak boleh dengan cara memaksa atau memerintah. Hal ini dikarenakan, cara yang lembut lebih melekat kepada anak dan akan berbekas positif dibandingkan cara yang kasar atau memaksa.

Berdasarkan hasil observasi lapangan pada beberapa lembaga PAUD di Kecamatan Kamal menunjukkan bahwa dalam penerapan pembelajaran matematika guru hanya menggunakan teknik pengenalan konsep matematika melalui hapalan lagu dan berhitung. Yang mana dengan cara tersebut siswa cenderung menghapal konsep tanpa tahu makna dan dari mana konsep matematika tersebut dibangun, sehingga pola berpikir siswa menjadi kurang kritis. Oleh karena itu, perlu dilakukan pembenahan pembelajaran 
dengan melatih proses berpikir kritis siswa sejak dini.

Berdasarkan uraian di atas, maka peneliti mengangkat penelitian tentang Profil Kemampuan Matematika Anak Usia Dini dalam Learning To Think Different.

\section{Hakikat Matematika}

Matematika sebagai ilmu memiliki karakteristik, yaitu (1) memiliki objek kajian abstrak, (2) bertumpu pada kesepakatan, (3) berpola pikir deduktif, (4) memiliki simbolsimbol yang kosong arti, (5) memperhatikan semesta pembicaraan, dan (6) konsisten dalam sistemnya (Soedjadi, 2000). Sifat konkret objek kajian matematika pada anak usia dini diusahakan lebih banyak atau lebih besar dari pada di jenjang sekolah yang lebih tinggi. Semakin tinggi jenjang sekolahnya, semakin besar atau banyak sifat abstraknya. Jadi, pembelajaran tetap diarahkan kepada pencapaian kemampuan berpikir abstrak para siswa.

Dalam matematika sekolah dapat digunakan pola pikir deduktif maupun induktif. Hal ini karena dalam penerapan pembelajaran matematika diharapkan siswa mampu berpikir deduktif, namun dalam prosesnya dapat digunakan pola pikir induktif. Pola pikir induktif yang digunakan dimaksudkan untuk menyesuaikan dengan tahap perkembangan intelektual siswa.

\section{Learning To Think Different}

Learning to think different merupakan salah satu teknik pembelajaran matematika anak usia dini yang didalamnya melatihkan kemampuan berpikir kritis dengan sudut pandang cara berpikir yang berbeda atau yang biasa disebut dengan istilah Think-Outof-the Box. Berpikir kritis berbeda dengan berpikir biasa atau berpikir rutin. Berpikir kritis merupakan proses berpikir intelektual di mana pemikir dengan sengaja menilai kualitas pemikirannya, pemikir menggunakan pemikiran yang reflektif, independen, jernih dan rasional.

Berpikir kritis mencakup ketrampilan menafsirkan dan menilai pengamatan, informasi, dan argumentasi. Berpikir kritis meliputi pemikiran dan penggunaan alasan yang logis, mencakup ketrampilan membandingkan, mengklasifikasi, melakukan pengurutan (sekuensi), menghubungkan sebab dan akibat, mendeskripsikan pola, membuat analogi, menyusun rangkaian, memberi alasan secara deduktif dan induktif, peramalan, perencanaan, perumusan hipotesis, dan penyampaian kritik. Berpikir kritis mencakup penentuan tentang makna dan kepentingan dari apa yang dilihat atau dinyatakan, penilaian argumen, pertimbangan apakah kesimpulan ditarik berdasarkan bukti-bukti pendukung yang memadai.

Berpikir kritis memerlukan upaya terus-menerus untuk menganalisis dan mengkaji keyakinan, pengetahuan yang dimiliki, dan kesimpulan yang dibuat, dengan menggunakan bukti-bukti yang mendukung. Berpikir kritis membutuhkan kemampuan untuk mengidentifikasi prasangka, bias (keberpihakan), propaganda (misalnya, propaganda perusahaan obat), kebohongan, distorsi (penyesatan), misinformasi (informasi yang salah), egosentrisme, dan sebagainya. Berpikir kritis mencakup kemampuan untuk mengenali masalah dengan lebih tajam, menemukan cara yang dapat dilakukan untuk mengatasi masalah tersebut, mengumpulkan informasi yang relevan, mengenali asumsi dan nilainilai yang ada di balik keyakinan, pengetahuan, maupun kesimpulan. Berpikir kritis mencakup kemampuan untuk memahami dan menggunakan bahasa dengan akurat, jelas, dan diskriminatif (yakni, melihat dan membuat perbedaan yang jelas tentang setiap makna), kemampuan untuk menafsirkan data, menilai bukti-bukti dan argumentasi, mengenali adatidaknya hubungan yang logis antara dugaaan satu dengan dugaan lainnya. 
Berpikir kritis dapat terjadi ketika seorang membuat keputusan atau memecahkan suatu masalah. Ketika seorang mempertimbangkan apakah akan mempercayai atau tidak mempercayai, melakukan atau tidak melakukan suatu tindakan, atau mempertimbangkan untuk bertindak dengan alasan dan kajian yang kuat, maka ia sedang menggunakan cara berpikir kritis. Seorang yang berpikir kritis akan mengkaji ulang apakah keyakinan dan pengetahuan yang dimiliki atau dikemukakan orang lain logis atau tidak. Demikian juga seorang yang berpikir kritis tidak akan menelan begitu saja kesimpulan-kesimpulan atau hipotesis yang dikemukakan dirinya sendiri atau orang lain. Seorang pemikir kritis memiliki sejumlah karakteristik sebagai berikut:

1 Mengemukakan pertanyaan-pertanyaan dan masalah penting, merumuskannya dengan jelas dan teliti

2 Memunculkan ide-ide baru yang berguna dan relevan untuk melakukan tugas. Pemikiran kritis memiliki peran penting untuk menilai manfaat ide-ide baru, memilih ide-ide yang terbaik, atau memodifikasi ide-ide jika perlu

3 Mengumpulkan dan menilai informasiinformasi yang relevan, dengan menggunakan gagasan abstrak untuk menafsirkannya dengan efektif

4 Menarik kesimpulan dan solusi dengan alasan yang kuat, bukti yang kuat, dan mengujinya dengan menggunakan kriteria dan standar yang relevan

5 Berpikir terbuka dengan menggunakan berbagai alternatif sistem pemikiran, sembari mengenali, menilai, dan mencari hubungan-hubungan antara semua asumsi, implikasi, akibat-akibat praktis

6 Mampu mengatasi kebingungan, mampu membedakan antara fakta, teori, opini, dan keyakinan

7 Mengkomunikasikan dengan efektif kepada orang lain dalam upaya menemukan solusi atas masalah- masalah kompleks, tanpa terpengaruh oleh pemikiran orang lain tentang topik yang bersangkutan

8 Jujur terhadap diri sendiri, menolak manipulasi, memegang kredibilitas dan integritas ilmiah, dan secara intelektual independen, imparsial, netral.

Menurut Krulik dan Rudnick (dalam Ismail, 2013:72) untuk dapat mengembangkan keterampilan berpikir kritis siswa, guru perlu mencari strategi yang tepat dalam pembelajaran yang dilakukannya. Pertanyaanpertanyaan yang bersifat kritis dapat diajukan guru pada siswanya. Terdapat bermacammacam contoh pertanyaan kritis misalnya, Apakah ada cara lain? Apakah jika ...? Apa yang salah? Melalui latihan seperti ini kepada siswa akan dapat mendorong mereka berpikir kreatif yang dapat meningkatkan ketrampilan berpikir kritis.

\section{METODE}

Penelitian tentang Profil Kemampuan Matematika Anak Usia Dini dalam Learning To Think Different ini termasuk jenis penelitian eksploratif dengan pendekatan kualitatif. Penelitian dilakukan di TK Al Hikmah Kecamatan Kamal.

Penelitian ini melibatkan secara penuh peneliti sebagai instrumen penelitian yang dibantu oleh instumen lain melalui teknik pengumpulan informasi sebagai berikut.

\section{a. Tes Torrance}

TesTorrance ini untuk mengukur kemampuan berpikir kritis dan kreatif anak.

b. Wawancara

Wawancara yang dilakukan dalam penelitian ini bertujuan untuk menginvestigasi proses berpikir kritis siswa. 
Data hasil penelitian ini dianalisis dengan analisis kualitatif yang meliputi reduksi data, pemaparan data, dan penarikan kesimpulan.

\section{HASIL DAN PEMBAHASAN}

Pada penelitian ini subjek yang diteliti adalah anak kelompok B usia 5-6 tahun. Untuk selanjutnya dalam menentukan subjek penelitian, peneliti mengamati kemampuan awal matematika anak melalui tes psikologi sebelum pembelajaran dilaksanakan. Tes psikologi ini dilakukan dalam satu hari, mengingat jumlah anak yang dites hanya 13 anak. Pada saat tes berlangsung anak hanya mengikuti petunjuk dari psikolog karena ratarata anak belum mampu membaca instruksinya secara mandiri. Dari kegiatan ini diperoleh hasil kemampuan matematika anak bahwa terdapat 2 (dua) kelompok anak berdasarkan hasil tes psikologi, yaitu anak dengan kemampuan di bawah rata-rata dan anak dengan kemampuan rata-rata. Ada sebanyak 6 anak termasuk dalam kategori di bawah ratarata dan 7 anak pada kategori rata-rata. Oleh karena itu, dalam penelitian ini subjek penelitian juga terbagi menjadi 2 (dua) kelompok, yakni anak dengan kemampuan di bawah rata-rata dan anak dengan kemampuan rata-rata.

Pada saat hari pertama pengumpulan informasi, anak-anak belajar dengan learning to think different melalui kegiatan pembelajaran tema Kebutuhanku dan subtema Makanan. Dalam pembelajaran tersebut anak mengenal makanan 4 sehat 5 sempurna. Pembelajaran dengan learning to think different ini anak belajar tentang konsep matematika melalui media 3 dimensi bentuk makanan/minuman.

Selain itu, pembelajaran pada hari pertama ini membelajarkan anak dalam mengemukakan idenya dalam memilih dan menentukan jumlah makanan sehat yang dibutuhkan. Dalam kegiatan ini anak sangat senang, anak-anak sangat antusias mengikuti pembelajaran. Hal ini karena anak bebas mengutarakan pendapatnya dan menunjukkan pemahamannya dalam pemecahan masalah.

Pada hari kedua pengumpulan informasi ini, dengan tema dan subtema yang sama dengan pertemuan sebelumnya, anak belajar berhitung bagaimana menunjukkan konsep bilangan dengan jari mereka, tetapi dengan cara yang berbeda. Misal, menunjuk konsep 2 (dua), anak dapat menggunakan 2 jari mereka dengan ibu jari dan jari telunjuk atau 1 jari telunjuk tangan kanan dan 1 jari telunjuk tangan kiri, dan sebagainya.

Tidak hanya belajar berhitung dengan jari mereka, anak-anak juga belajar tentang konsep klasifikasi dan pola, yang mana merupakan salah satu konsep matematika sederhana. Anak belajar berpikir logis dari benda yang ada di sekitarnya. Anak mengklasifikasikan benda berdasarkan warna, bentuk, dan ukuran (3 variasi); membuat pola ABCD-ABCD; dan mengurutkan benda berdasarkan ukurannya. Anak sangat senang, karena biasanya mereka hanya belajar matematika konsep angka-angka dengan media papan tulis atau LKA (Lembar Kerja Anak).

Adapun pada hari ketiga pengumpulan informasi, anak belajar dengan learning to think different berbantuan media Funtastic Learning, yakni media berupa buku panduan belajar yang dilengkapi dengan kotak pas yang dapat dimainkan. Anak belajar sambil bermain, khususnya belajar pemecahan masalah. Anak dihadapkan pada papan maze, yang mana anak dituntut dalam memecahkan masalahnya yakni menemukan lintasan yang cocok dengan permasalahan yang dihadapi. Selain itu, pada hari tersebut anak juga diberikan kesempatan bebas berekspresi menggambar bentuk geometri sesuai dengan gagasannya dan menirukan bentuk benda yang ada di sekitar. 
Selama dilakukan pembelajaran dengan learning to think different ini anak diberikan tes Torrance untuk mengetahui kemampuan berpikirnya yang terdiri dari bentuk verbal dan bentuk figural. Tes tersebut disusun untuk membuat aktivitasnya menarik dan menantang bagi anak mulai dari pra sekolah sampai tamat sekolah menengah (Siswono, 2008: 19). Penilaian tes Torrance ini didasarkan pada indikator pencapaian perkembangan anak yang diteliti sebagaimana yang tertera pada STPPA untuk anak usia 5-6 tahun. Skala penilaian yang digunakan adalah skala Likert dengan 4 opsi, yaitu 1 (Belum Berkembang atau BB), 2 (Mulai Berkembang atau MB), 3 (Berkembang Sesuai Harapan atau BSH), dan 4 (Berkembang Sangat Baik atau BSB). Adapun hasil rekapitulasinya diperoleh sebagaimana yang disajikan pada tabel 1 berikut.

Pada tabel 1 tersebut diperoleh gambaran secara umum kedua kelompok anak tersebut tidak terlalu berbeda kemampuannya. Keduanya berbeda hanya dalam hal kemampuan pemecahan masalahnya. Anak dengan kemampuan di bawah rata-rata diketahui dengan kategori MB. Dalam hal ini berarti bahwa kemampuan anak mulai berkembang, anak dapat melakukan aktivitasnya akan tetapi masih membutuhkan bantuan orang lain (baik teman, guru, orang tua, atau orang yang di sekitarnya) dalam memecahkan masalah. Sedangkan anak dengan kemampuan rata-rata termasuk dalam kategori BSH. Hal ini mengindikasikan bahwa kemampuan anak pada kelompok tersebut sudah sesuai dengan harapan guru meskipun belum sepenuhnya sempurna. Adakalanya anak dapat menyelesaikan tugasnya dalam kurun waktu relatif lama.

Berdasarkan tabel 1 tersebut, kemampuan anak di bawah rata-rata sama dalam hal kemampuan berpikir logis, simbolik, dan kritis. Pada kemampuan berpikir logis dan simbolik, kemampuan anak tergolong kategori BSH. Artinya, kemampuan anak sudah sesuai dengan harapan meski belum sempurna. Sedangkan pada kemampuan berpikir kritis, anak termasuk pada kategori MB (mulai berkembang). Hal ini menunjukkan bahwa diantara kedua kelompok anak tersebut kemampuannya masih cukup baik. Anak masih membutuhkan bantuan orang lain untuk dapat menyelesaikan tugasnya.

Anak usia 5-6 tahun menurut Jean Piaget tergolong pada tahap pra operasional (18 bulan -6 tahun). Anak usia dini pada tahap ini dapat menggunakan simbol dan pikiran internal dalam memecahkan masalah. Pikiran anak-anak pada tahap ini masih terkait dengan objek kongkrit saat, ke-kini-an, dan kebaru-an (Suyadi, 2010: 86). Ole karena itu, pada anak usia 5 - 6 tahun, idealnya anak diharapkan mampu berpikir kritis dan kreatif. Berpikir kritis dan kreatif ini digunakan anak khususnya dalam pemecahan masalah kehidupan sehari-hari. Hal ini sejalan dengan pendapat Johnson (2002, dalam Siswono, 2008: 15) bahwa berpikir kritis mengorganisasikan proses yang digunakan dalam aktivitas mental seperti pemecahan masalah, pengambilan keputusan, meyakinkan, menganalisis asumsi-asumsi dan penemuan ilmiah. Sedangkan berpikir kreatif merupakan suatu aktivitas mental yang memperhatikan keaslian dan wawasan (ide).

Dalam penelitian ini, anak yang memiliki wawasan yang luas tentang benda di sekitarnya cenderung memiliki daya imajinasi yang berbeda dan lebih tinggi dibandingkan anak-anak lainnya. Dalam hal berhitung, anak mampu mengoperasikan bilangan-bilangan yang berbeda untuk menghasilkan satu bilangan yang sama. Anak yang kritis dan kreatif mampu menggambar bentuk geometri sejauh imajinasinya memandang. Anak bebas mengekspresikan daya imajinasinya dari sudut pandang yang berbeda. Seperti halnya yang dilakukan oleh 4 (empat) anak, yaitu fhr, ibr, shr, dan gbr.

Fhr (5 th 10 bln) mampu menggambarkan suasana lingkungan dengan 
adanya seekor pinguin dan 2 (dua) anak kecil sedang bermain bola di lapangan. Ekspresi anak dalam gambar tersebut ceria. Dari hasil wawancara dengan fhr bahwa "anak - anak itu senang kalau diajak bermain, kalau sedih tidak usah main". Lain halnya dengan ibr (5 th 9 bln), dia menggambar buah kesukaannya (pisang) dengan warna merah yang dilengkapi dengan gambar tanda panah besar yang menunjuk ke arah pisang. Menurut ibr, "pisang itu tidak selalu kuning, ada kok pisang yang warnanya merah". Lalu ibr juga menambahkan bahwa tanda pana yang ia gambar menunjukkan penekanan (fokus) bahwa ibr sangat suka dengan pisang.

Shr (4 th 6 bln) menggambar seekor kuda yang sedang berlari. Menurut shr, "aku suka naik kuda, biasanya aku naik kuda kalau ikut ke pasar". Dari gambar yang dibuat ole shr, shr sdah mampu menggambar bentuk geometri bagian-bagian anggota tubuh kuda meski tidak sempurna dan shr merupakan anak termuda di kelasnya. Gbr (5 th 7 bln) menggambar sebuah rumah dengan komposisi bentuk geometri segitiga besar sebagai atapnya, persegi sebagai jendela, persegi panjang sebagai bangunan rumahnya, dan segitiga kecil sebagai pintunya. Dari hasil wawancara dengan gbr, menyatakan bahwa gbr suka dengan rumah dengan pintu yang unik (segitiga). Menurut gbr, "kalau bentuknya persegi panjang tidak bagus, sudah biasa".

Berdasarkan paparan di atas menunjukkan bahwa keempat anak tersebut mampu mengungkapkan idenya yang berbeda dan menuangkannya dalam bentuk gambar. Ide tersebut berasal dari banyaknya pengalaman yang mereka dapatkan sebelumnya dengan lingkungan sekitar mereka. Semakin banyak pengalaman yang mereka alami, maka semakin banyak pula wawasan maupun pengetahuan yang mereka miliki. Wawasan dan pengetahuan inilah yang nantinya membantu mereka dalam berpikir kritis dan kreatif untuk memecahkan masalah mereka.
Peneliti menemukan beberapa temuan dalam penelitian ini, khususnya terkait dengan pemahaman konsep matematika. Hal ini yang biasa disebut dengan miskonsepsi. Miskonsepsi yang dimaksud adalah anak sering melakukan kesalahan konsep dalam penulisan lambang bilangan. Anak sebenarnya sudah paham tentang konsep nama bilangan dan arti dari bilangan. Akan tetapi ketika berhadapan dengan permasalahan sehari-hari, khususnya yang melibatkan konsep bilangan, anak masih bingung dalam penulisan lambang bilangannya. Misalnya, dalam menulis 3, 5, 7, 6, dan 9. Anak sering salah posisi hadapnya dalam penulisan angka-angka tersebut.

Selain itu, karena anak terbiasa dengan pembelajaran berbasis LKA, maka pembelajaran terkesan monoton. Pada akhir pembelajaran, masih banyak anak yang masih belum paham konsepnya. Anak juga menjadi penurut, kurang kritis dan kreatif dalam pembelajaran. Anak-anak tidak secara bebas mengungkapkan idenya. Lagi pula, anak jarang dilatihkan untuk menggambar bentuk sesuai dengan keinginan mereka, anak hanya dilatihkan mewarnai gambar. Hal ini menyebabkan beberapa anak masih kesulitan ketika meniru bentuk geometri benda yang ada di sekitarnya dan menggambar geometri bebas sesuai dengan gagasan masing-masing anak.

Melalui pembelajaran learning to think different ini anak lebih bebas berekspresi. Mereka dapat bebas menuangkan segala ide mereka. Melalui pembelajaran ini, anak juga dilatihkan untuk mengasah beberapa kemampuannya, khususnya berpikir logis, simbolik, kritis, dan pemecahan masalah. Dengan harapan, anak mampu mengembangkan kemampuan mereka dengan lebih baik, khususnya pada kemampuan berpikir berbeda dalam matematika nantinya. 


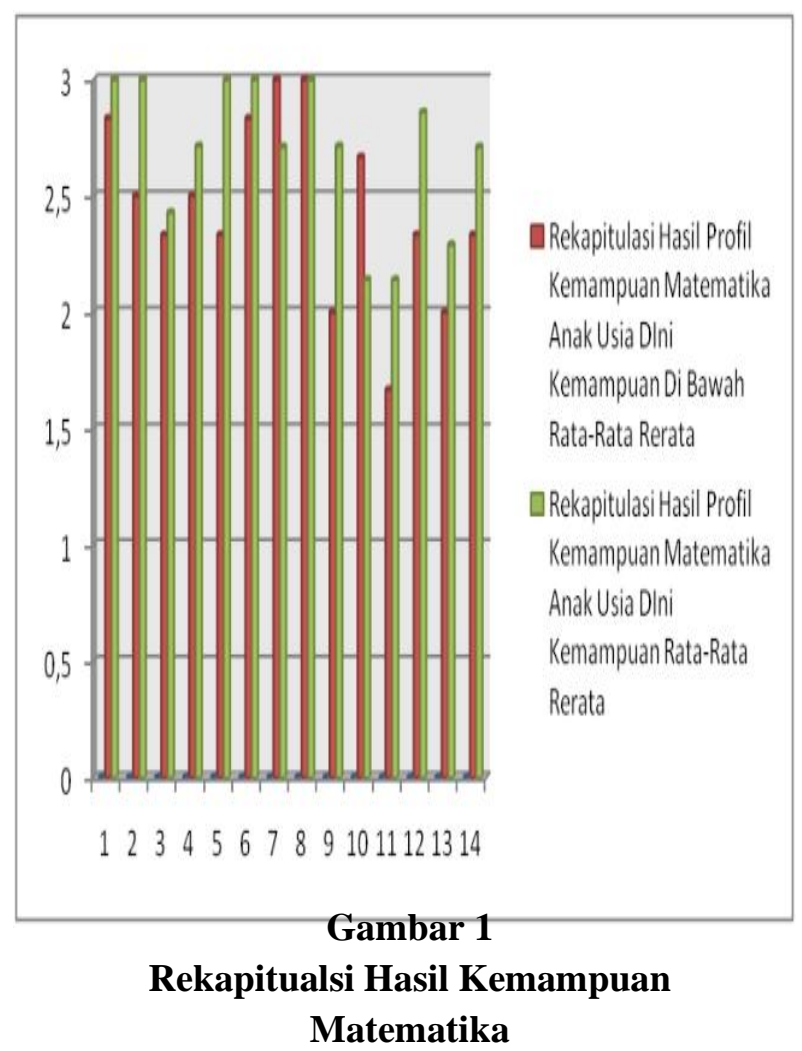

\section{SIMPULAN}

Berdasarkan pada paparan permasalahan, hasil dan pembahasan di atas, dapat disimpulkan bahwa gambaran profil kemampuan matematika anak usia dini dikategorikan berdasarkan hasil tes psikologi, yaitu kelompok anak dengan kemampuan di bawah rata-rata dan kelompok anak dengan kemampuan rata-rata. Pada kelompok anak dengan kemampuan di bawah rata-rata memiliki kesamaan dengan kelompok rata-rata dalam kemampuan berpikir logis dan simbolik yaitu kategori berkembang sesuai harapan. Adapun untuk kemampuan berpikir kritisnya sama, yakni kategori mulai berkembang. Kelompok anak dengan kemampuan di bawah rata-rata memiliki kemampuan pemecahan masalah dengan kategori mulai berkembang, sedangkan kelompok anak dengan kemampuan rata-rata termasuk kategori berkembang sesuai dengan harapan.

\section{Saran}

Setelah melakukan penelitian ini, ada beberapa rekomendasi kepada beberapa pihak. Rekomendasi tersebut antara lain; orang tua sebaiknya melatihkan konsep berpikir kritis dan kreatif dalam aktivitas keseharian dengan anak, sehingga kemampuan anak dalam berpikir kritis dan kreatif dimiliki sejak dini.

Sekolah, khususnya untuk guru, diharapkan dapat membuat perencanaan pembelajaran yang dapat menumbuhkan kemampuan berpikir kritis dan kreatif kepada anak didiknya sehingga kemamapuan tersebut dapat menjadi bekal untuk pemecahan masalah pada jenjang pendidikan selanjutnya.

Peneliti selanjutnya diharapkan dapat lebih mengembangkan kajian berpikir kritis dan kreatif dalam bingkai desain pembelajaran matematika untuk anak usia dini yang lainnya.

\section{DAFTAR PUSTAKA}

Ayuningtyas, N. dan Endah B., R. 2013. Proses Berpikir Siswa SMP dalam Menyelesaikan Soal Higher Order Thinking Pada Materi Aljabar. Surabaya: UNESA. Dipublikasikan pada Prosiding Seminar Nasional Matematika dan Pendidikan Matematika Unesa 2013.

Idris, M., H. 2015. Stategi Pembelajaran yang Menyenangkan. Jakarta Timur: Luxima.

Ismail. 2013. Identifikasi Keterampilan Berpikir Kritis dan Hubungannya dengan Keterampilan Metakognitif pada Siswa SMP dalam Menyelesaikan Soalsoal Berpikir Kritis Masalah Matematika. Surabaya: UNESA. Dipublikasikan pada Prosiding Seminar Nasional Matematika dan Pendidikan Matematika Unesa 2013.

Nisa', T. F., Karim, M. B., \& Mayangsari, D. 2016. Membangun Karakter Anak Usia 
Dini Melalui Pembelajaran Math Character. Jurnal PEDAGOGIA, 5 (2): 113-124

Putra, N. dan Dwilestari, N. 2013. Penelitian Kualitatif PAUD. Jakarta: Rajawali Pres.

Siswono, T. Y. E. 2008. Model Pembelajaran Matematika Berbasis Pengajuan dan Pemecahan Masalah untuk Meningkatkan Kemampuan Berpikir Kreatif. Surabaya: Unesa University Press

Soedjadi, R. 2000. Kiat Pendidikan Matematika di Indonesia. Surabaya: Direktorat Jenderal Pendidikan Tinggi Departemen Pendidikan Nasional

Suhartiningsih, I., Budhojo, K., \& Sutansi. Peningkatan Kemampuan Kognitif Melalui Kegiatan Bermain Lompat Angka Berantai Pada Anak Kelompok A TK Dharma Wanita Lirboyo Kota Kediri. Jurnal PAUD, 1 (2): 75-79

Sujiono, Y., N. 2013. Konsep Dasar Pendidikan Anak Usia Dini. Jakarta Barat: Indeks

Suparno, P. 2001. Teori Perkembangan Kognitif Jean Piaget. Yogyakarta: Kanisius

Suyadi. 2010. Psikologi Belajar Pendidikan Anak Usia Dini. Yogyakarta: Pedagogia.

Tim Redaksi Noura Books. 2016. FUNtastic Learning with Nabil \& Naura. (Angka). Jakarta Selatan: Noura Books PT Mizan Publika (Anggota IKAPI) 